\title{
Globalization and Technological Innovation: Which Impact on the Rise of Unemployment?
}

\author{
Rahman Olanrewaju Raji ${ }^{1}$ \\ ${ }^{1}$ Canterbury International High School, Lekki-Ajah, Lagos, Nigeria \\ Correspondence: Rahman Olanrewaju Raji, Canterbury International High School, Lekki-Ajah, Lagos, Nigeria. \\ Tel: 234-802-309-7110. E-mail: rahman.raji@rocketmail.com/rahmandole@gmail.com
}

Received: November 11, 2020 Accepted: December 8, 2020 Online Published: December 31, 2020

\begin{abstract}
This paper explores the asymmetric nexus between globalization, technological innovation and unemployment within non-linear Autoregressive Distributed Lag (NARDL) framework, Granger causality approach and forecast error variance decomposition technique, covering the period from 2000 to 2018, using quarterly data in Nigeria. To avoid variable omission bias, the study incorporated control variables. The findings showed that both the positive and negative shock of our variables of study indicate varying signs and magnitudes and there is a mixed presence of asymmetries among the nexus, as indicated in the variables for both short and long runs. The results implies that trade globalization, financial globalization and technological innovation biased process innovation contributed to the persistent increase in unemployment rate except technological innovation biased product innovation, which supported the unemployment reduction in Nigeria. These findings were not consistent with existing theories. The results based on the model and empirical data suggest that the authority needs to initiate socially suitable and economic schemes and strategies by ensuring effective and efficient connectivity between globalization and technology via integrating science, technology, research and development. Also, creating an enabling environment that supports and promotes sound and credible government institutions and education including adequate mechanism to ensure optimum utilization of scare resources and avoidance of embezzlement of these limited resources by corrupt officials.
\end{abstract}

Keywords: globalization, technological innovation, unemployment, Non-ARDL framework

\section{Introduction}

There are macroeconomic objectives that economies tend to attain at every point in time, which include a reduction in the unemployment rate and income inequality. To achieve these, globalization and technology are widely identified as the main and key driving forces, tending to foster growth and development of an economy, which indeed can combat unemployment and inequality rates. These driving forces are not independent of each other, and are indeed closely related. It has been established that the spread of globalization is a result of diffusion of technological transfer, and diffusion of technological transfer is a result of the continuous spread of globalization.(Bhattacharya et al., 2016; Qadri et al., 2018). By implication, this suggests that there is a bi-causal relationship, whereby technology promotes globalization and globalization also drives technology in the course of reducing unemployment and income inequality that promotes economic growth and development. Stewart et al. (2015) viewed technological innovation as a driving propeller of new industries followed by the development of products meeting unfulfilled human needs and wants. It means that employment opportunities are created with a likely increase in production, which, in turn, boost economic growth and income with an overall reduction in inequality in the society. More importantly, it promotes productivity, which amounts to driving down production cost and product prices. Whereas globalization spurs economic growth and mitigates unemployment and inequality rates by encouraging countries to engage in trade openness and financial openness. This contends that, globalization stimulates profitability as a result of the innovation activity of exporting firms, either domestic or foreign firms. This tends to raise profit, which in turn, encourages more firms to embark on technological innovation, leading to an increase in productivity and demand for labour (Kilic, 2015; Dritsakis, 2014)

The good connection between economic globalization and technological innovations improves economic growth, by de-escalating the rise of unemployment rate and income inequality. However, the bad liaison between the influencing forces (economic globalization and technological innovation) hinders some macroeconomic objectives, such as a reduction in unemployment rate and income inequality, despite their positive impacts on economic 
growth in most economies. Andrews et al. (2016) reiterated that technologies were developed faster, where their adoption was quickly undertaken by leading firms, leaving lagging firms behind the technological advancement. This suggests that, slow diffusion of technological waves due to monopolistic or capitalistic style tends to increase barriers of entry for laggard firms to partake in new technology in due course. These leading firms will benefits earlier, which accelerates their productivity growth, thereby income inequality with implication on demand for labour has already been established. Qadri et al. (2018) argued that the bad connection between the economic globalization and technological innovation results in the combined backwash effects of globalization and technology, outweighed their combined spread effects. This could be attributed to a bad interaction and mismanagement between the two influencing forces. The overall outcome of such poor connection, bad interaction, and mismanagement between economic globalization and technological innovation aggregated to inequalities within the country and among the countries

The facilitation of economic globalization through technological innovation has heightened the benefits of being larger than rival firms due to the limitation of diffusion of new technology to other firms, in terms of restrictive property regulations and huge capital base. Helpman et al. (2010) posit that, as restrictive measure of economic globalization is relaxed, the profitability of exporting firms improves, leading to an expansion of the sector. Unemployment is likely to increase, when there is a mismatch in skill requirement amounting to laying off of unskilled workers. Janiak (2013) establishes that economic globalization exposure is associated with a higher level of equilibrium in unemployment, such that job destruction emanates from the movement of small low productivity firms exceeding job creation by large high-productivity firms. These larger firms will be benefitting from higher rents by limiting the size of job creation. Autor et al. (2017) agree with Janiak (2013) that winner-takes-all or winner-takes-most; these super-star firms dominate and control the market, including profit. This will decline labour share of income across industries, which dampens income inequality and unemployment in the economies.

Kim (2011) claims that skilled-biased technological innovation decreases demand for labour services due to spread of economic globalization through importation of capital goods, including increase in foreign direct investment from advanced economies. These could increase demand for highly skilled workers, and consequently, income inequality rises. These demonstrate that as economic globalization increases innovation activity through research and development, demand for highly skilled labour tends to increase more turnover rate of unskilled workers speeding up the creative destruction process and frictional unemployment. Krugman (2012) realized that, capital intensive technological innovation promoted income inequality as labour input was replaced with more productive input - capital towards production. The return of the capital owner improved at the expense of return of labour owners due to skill-biased technological innovation. This had escalated unfair distribution of compensation among production inputs (income inequality).

The failure of policy planners, policy makers and authority without political will to initiate and develop strategies and policies, towards a good liaison between economic globalization and technology devastates economic system, whereby market failure and poor knowledge base of the society are established. Inability to ensure a good connection between economic globalization and technology, on one hand, and economy and technology on other hand, market failure will generate waste of resources, uneven distribution of resources, degradation of the environment, and the overall adverse impact, loss of output growth and development, which in turn, escalate unemployment and inequality in the society at large.

There are a quite number of studies, which capture the impact of either trade openness on unemployment or the nexus between financial openness and unemployment, whereas some studies focused on the technologyunemployment relationship. The strand of literature on the simultaneous effect of these two influencing variables on unemployment rates is scanty. This study explores the non-linear ARDL co-integration approach, an issue that appears to be ignored in this specific area of study and also to check the shortcoming of the existing studies. In addition, the study tests causality between these variables, including control variables (income inequality and inflation). This causality direction between candidate variables can implant the strategies and policies, thereby can enhance a good connection between economic globalization and technological innovation in achieving macroeconomic goals. This is because the strategic and policy direction are very important for the improvement of sustainability in the economy, in a small-open economy like Nigeria, by assessing causal effect of economic globalization and technological innovation on unemployment.

\section{Literature Review}

Based on the findings that there is a connection between globalization and unemployment. One leading key factor receiving an interesting attention is the effect of either trade openness on unemployment or financial openness (FDI) on unemployment. Studies like Onanuga et al. (2018), Johnny et al (2018). Daly (2017), Adamu et al. (2017), 
Matthew and Ogunlusi (2017), Awad et al. (2016) are among the few empirical studies that have conducted nexus either between trade openness and unemployment or financial openness and unemployment.

Zeb et al. (2014) evaluated the association between globalization and unemployment rate in Pakistan spanning from1995 to 2011. The results indicate that the globalization participated in the reduction of unemployment in Pakistan exploring multiple regression analysis. These findings are in conformity with Daly (2017) examining the globalization impact on unemployment in Pakistan using annual data over a period from 1980 to 2013. The Autoregressive distributive lag results indicated that economic globalization had optimistic impact on the reduction of unemployment rate. Adamu et al. (2017) is consistent with Zeb et al (2014) and Daly (2017) assessed the impact of globalization on unemployment in 35 countries in Sub-Saharan African for the period 2007-2014, using the Generalized Method of Moments estimation technique. Findings show that aggregated globalization measures (economic, social and political) significantly impact unemployment rate in SSA

In Alawin's study (2013) on the trade balance and unemployment in Jordan, using quarterly data for the 20002012 period. His major findings revealed the absence of a long-term relationship whereas in the short-term, a trade balance deficit promoted unemployment and vice versa. In a similar vein, Meidan (2012) investigated trade intensity index as measure of globalization on unemployment in Iran during the period 1971 to 2006, using the Johansen-Juselius co-integration test. Their outcomes implied that the globalization had a significant and negative effect on the unemployment rate.

Hahn and Park (2011) suggested that in the Korean manufacturing sector, export spurred employment of the skilled workers with a less beneficial effect on the unskilled workers, since the pace of globalization in the nineties. In conformity with Hahn and Park (2011), Awad et al's assessment (2016) indicated economic globalization has positive and significant impact on the reduction of unemployment in Malaysia between the period of 1980 and 2014 according to the ARDL approach explored in their study

Anyanwu (2014) disclosed that intra-African trade contributed to the drastic reduction in the youth unemployment, except the effects of trade liberalization on the aggregate unemployment rate, which were ambiguous. Anyanwu (2014) deviated from Kim (2011) who tested the effects of trade on unemployment from 20 OECD countries 19612008 using the OLS approach. The results pinpointed that a rise in trade openness dampened an aggregate unemployment in a rigid labour market institutions, whereas in a flexible one, trade tended to reduce the aggregate unemployment. Similarly to Kim (2011), Görg and Görlich (2011) stated that the probability of switching into unemployment was positively associated with the export share in Germany; as individuals in export firms with higher exports are more likely to lose their jobs if measures were not in place.

Nwaka (2015) investigated the impacts of trade policy on the unemployment rates in Nigeria from 1970 to 2010. The vector error correction method used showed that the trade openness policy was associated with an increase in unemployment in the long run, but short-term dynamics noticed the trade openness reducing the unemployment in this economy, whereas Aremo et al. (2010) argued that globalization practice generated negative impact on the employment in both short- and long-run periods in Nigeria and if globalization continues as being practiced, it could further worsen the state of unemployment in the economy

Lipsey et al. (2010) realized in their research on a large sample of Indonesian plants for the period $1975-2005$ that the employment growth occurred as result of shifting from local ownership of companies to foreign ownership had a significant effect in growing the employment in Indonesian economy. Shaar et al. (2012) drew a related conclusion with Lipsey et al. (2010) who assessed the FDI- unemployment nexus in Malaysia from 1980 to 2010. The result from the ordinary least square indicated a negative relationship between foreign direct investment and unemployment rate in Malaysia.

Matthew and Ogunlusi (2017) examined the relationship between foreign direct investment and employment generation in Nigeria between 1981 and 2014 using the Johansen co-integration and VEC. The result revealed that foreign direct investment had a positive and significant relationship with the employment generation in Nigeria. This conclusion contradicted Johnny et al.'s findings (2018). Based on their study, the impact of foreign direct investment on the unemployment rate in Nigeria from 1980 to 2015, findings from the co-integration test and ordinary least square approach revealed a negative and insignificant relationship between foreign direct investment and unemployment rate. Chella and Phiri (2017) agreed with Johnny et al.(2018), when similar study was conducted on South Africa. The outcomes of ARDL approach indicated that FDI had no significant influence on the unemployment reduction except domestic investment which had a significant positive impact on the employment growth rates.

Strata (2014) attempted to show a causality analysis between FDI and unemployment in the latest EU Members. His findings stipulated a causality relation running from the inflow of foreign direct investments towards the 
unemployment for four economies which include Hungary, Malta, Bulgaria and Estonia while the causal flow also runs from the unemployment towards the inflows of foreign direct investments for the case of Romania, the Czech Republic and Slovakia. Onanuga et al (2018) determined the influence of FDI on unemployment by adopting descriptive statistic and panel regression based on the Ordinary Least Squares Method on selected emerging economies from 2000 to 2015. Their results suggested that the net inflow of FDI has a negative influence on the unemployment rate due to government policy lacking significant effect on the net inflow of FDI in those economies. This study is not consistent with Zdravkovic et al. (2017) when conducting a study on transition countries spanning 2000 and 2014. The explored Panel co-integration framework implied that a loose relationship between FDI and unemployment was detected in the 17 transition economies studied.

Balcerzak et al. (2011) found that between 1995 and 2009 using the VAR approach to assess FDI and employment growth in Poland. It was found that in the short run, FDI had a positive and significant influence on the employment generation. This study agreed with Irpan, et al. (2016) supporting that unemployment rate of Malaysia was found to have been reduced by the inflow of FDI based on the ARDL approach, between a period of 1980 and 2012 . However, the relationship that exist between globalization (trade and financial aspects) and unemployment could be concluded to be mixed outcomes of most existing empirical findings. These could be attributed to sample periods and methodologies explored even macroeconomic situation of their key trading partners in relation to their own macroeconomic state.

In addition, there are studies clarifying the nexus between technology and unemployment where considerable attention is technological innovation either product innovation or process innovation on unemployment, such findings include Okumu et al. (2019), Fukao et al. (2017), Vashisht (2017), Matuzeviciute et al. (2017), Orji et al.(2016), Elejalde et al. (2015) based their empirical findings on the technological innovation-unemployment relationship.

Vashisht (2017) studied the impact of technology on employment and skill demand within Indian manufacturing sector. Findings disclosed that required labour per unit of output was reduced despite that, qualitative effect of process on employment (demand for labour) had been very significant in Indian manufacturing sector. Piva and Vivarelli (2017) contradicted Vashisht (2017) when utilizing longitudinal data from manufacturing and service sectors for 11 European countries, finding a negative correlation between employment and capital formation proxied by process innovation i.e. labor-saving giving that process innovation had been incorporated in investment. In conformity with Piva and Vivarelli (2017), Evangelista and Savona (2010) revealed that across service industry from the Italian economy from 1993 to 1995, their finding discovered an overall negative impact of innovation on employment. Specifically, small firms tended to have positive employment effect with higher level of innovation activity, whereas larger firms and capital-intensive industries indicated a negative employment impact of innovation.

Lachenmaier et al. (2011) carried out a study on the connection of technological innovation and employment rate in German manufacturing industry covering 1982 to 2002 using the GMM-SYS. Their outcomes suggested that a directly significant impact of both process and product innovation on employment. The observed estimates implied that a positive impact of process innovation was even higher than a positive effect of product innovation. In support of Lachenmaier et al. (2011), Okumu et al. (2019) validated employment growth was a positively and significantly associated with both process and product innovations when investigating the association between innovation and employment growth among manufacturing firms in Africa by exploring both the pooled ordinary least squares (OLS) and IV 2SLS techniques. Harrison et al. (2014) conducted a survey on 20,000 firms from four European countries (France, Germany, Spain and the UK) over a period from 1998 and 2000 to show the nexus between technological innovation and employment growth. Their findings indicated that a process innovation was responsible of employment displacement while an employment growth is positively associated with product innovation (labour friendly innovation). In validating Harrison et al. (2014), Dachs et al. (2017) established in their findings of the employment impact of technological innovation over the different phases of the business cycle by employing firm-level pooled data from 26 European countries over the period 1998-2010. The IV regressions made known that in all the phases of the business cycle, product innovations were labour friendly, while a labour displacement occurred during both upturn and downturn periods exhibited by process innovation and organisational changes. Elejalde et al. (2015) also agreed with Harrison et al. (2014) when conducting a study with a sample of 1415 firms in Argentina in order to investigate effect of technological innovation on unemployment rate. Findings showed that the product innovation had negative effect and significant impact on the unemployment growth except the effect of process innovation on the unemployment growth being neutral Sepehrdoust (2013) focused on the effects (ICT- mainly process innovation) on the employment level of selected OIC countries between 200 and 2009 using panel data model analysis. Findings showed that technological innovation enhanced 
major structural changes in the OIC member countries; there was a positive and significant effect of the ICTs on the employment rate. This study deviated from Orji et al. (2016), who estimated the impact of technological innovation (ICT usage) on the unemployment rate in Nigeria from 1985-2015 with the adoption of a classical linear regression model. Their estimates revealed that innovation proxied by ICT had a significant positive impact on the unemployment rate in the economy.

Fukao et al. (2017) found that the employment rate was positively associated with firm expenditure in R\&D biased (mainly product innovation) towards product innovation among services and high-tech manufacturing firms in the Japanese economy, when using microdata from the Basic Survey of Japanese Business Structure, whereas in Feldmann (2013) assessing the impact of technological unemployment exploring annual data of 21 industrial countries from 1985 to 2009 , his study showed no long-term effect. This indicated that the adverse effect on unemployment was more transitory than permanent, because technological change proxied by the ratio of triadic patent families to population (product innovation), was negatively correlated with the unemployment in the short term. In the same vein, Matuzeviciute et al (2017) disagreed with Feldmann (2013) arguing that an insignificant relationship between technological innovations proxied by triadic patent families per million inhabitants and unemployment existed when studying the impact of technological innovations on unemployment, using the panel data with (SGMM) from 25 European countries for the period of 2000-2012.

In conclusion, there is a concrete consensus from the existing and empirical studies that technological innovation biased process innovation contributed an adverse impact on the persistent rise in the magnitude of unemployment in most economies including developed one while product innovation (mainly related to research and development) had been an assisting and contributory factor reducing the danger of unemployment in most economies including developing one. Could it be as result of absence of intervening variables that could influence technological innovation on unemployment? This study attempts to overcome this limitation by exploring technological innovation indicators and globalization indicators simultaneously with control variables as intervening indicators (income inequality and inflation) on the unemployment rate, using the non-ARDL approach and Granger causality technique to determine the causal direction between those variables of interest and economic decisions.

\section{Method}

This study assesses whether technological innovation embodied in globalization instigates demand for highly skilled workers which causes further effect on the unemployment rate and escalates income inequality. Our estimation is not linked directly to any existing theory but to incorporate key variables into our model specification. Based on the research variables, the generalized form of the study model can be represented as follows:

$\begin{array}{ccccc}\text { Unemployment } & = & \text { Core Variables } & + & \text { Control Variables } \\ U M & = & X & + & C \ldots \ldots \ldots \ldots \ldots \ldots \ldots \ldots \ldots \ldots \ldots \ldots \ldots \ldots\end{array}$

where the core variables include globalization indicators and technological innovation indicators, then the control variable comprises of inflation and income inequality. Globalization indicators are captured by trade globalization (TG) whose proxy is import + export divided by GDP and financial globalization (FG) whose proxy is the inward FDI stock. Technological innovation indicators are captured by process innovation proxy by information technology investment (II), whereas product innovation is proxied by research and development expenditure (RI), which is introduced as total factor productivity. The control variables are income inequality captured with Gini coefficient (G) and inflation rate (INF). Inflation rate is a monetary variable which has direct or indirect impact on most macroeconomic parameters including unemployment while income inequality classified as a parameter which is attributed to be the consequence of adverse effect of technology and globalization resulting to unemployment via demand for highly skilled workers at the expense of low skilled worker

After transforming eq.1 into linear equation, it is represented as follows:

$$
U M_{t}=\alpha_{0}+\alpha_{1} X_{t}+\alpha_{2} C_{t}+\varepsilon_{t}
$$

All the variables in equation (2) such as $\mathrm{U}, \mathrm{X}$ and $\mathrm{C}$ are defined above, $\alpha_{1}$ and $\alpha_{2}$ represent long run elasticity, and $\varepsilon_{t}$ is the error correction term. Therefore, equation (2) indicates the long run effect on unemployment rate from a set of explanatory variables. To estimate long run co-integration and short run elasticity in the model, the study explores co-integrated test.

For empirical estimation, our study utilizes asymmetric or nonlinear autoregressive distributive lag (NARDL) model developed by Shin et al. (2014). This technique is relevant in our study as a result of its ability to distinguish between linear and nonlinear cointegration unlike most existing techniques which presume linear or symmetric effects of the movement of explanatory variables on a dependent variable. This study follows this technique to asses if a positive change and negative change in explanatory variables of the study have different effects on the 
dependent variable.

To develop full representation of the NARDL approach towards estimation of a nonlinear model to capture the asymmetric effect of core variables (globalization indicators and technological innovation indicators) of study on the unemployment rate, the linear equation (2) is converted into asymmetric long-run regression of unemployment rate which is specified as shown:

$$
U M_{t}=\alpha_{0}+\alpha_{11}^{-} X_{t}^{-}+\alpha_{12}^{+} X_{t}^{+}+\alpha_{2} C_{t}+\varepsilon_{t}
$$

From equation (3), the movement in core variables, $X_{t}$ are decomposed into its positive and negative partial sum i.e. $X_{t}=X_{t}^{-}+X_{t}^{+}$where $X_{t}^{-}$and $X_{t}^{+}$are the partial sum of the negative change (a decrease in core variables) in $X_{t}$ and sum of the positive change (an increase in core variables) in $X_{t}$ respectively. The formulation of partial sums of positive and negative changes is

$$
\begin{gathered}
X_{t}^{+}=\sum_{i=0}^{t} \Delta X_{t}^{+}=\sum_{i=0}^{t} \max \left(\Delta X_{t}, 0\right) ; \\
X_{t}^{-}=\sum_{i=0}^{t} \Delta X_{t}^{-}=\sum_{i=0}^{. t} \min \left(\Delta X_{t}, 0\right) ;
\end{gathered}
$$

where $X_{t}^{+}$indicates partial sum of a positive set of core variables: $T G_{t}^{+}+F G_{t}^{+}+R I_{t}^{+}+I I_{t}^{+}$and $X_{t}^{-}$ shows partial sum of a negative set of core variables: $T G_{t}^{-}+F G_{t}^{-}+R I_{t}^{-}+I I_{t}^{-}$respectively which have already been defined above. The parameters in equation (3) like $\alpha_{11}^{+}$captures the long-run effects between unemployment rate and its exogenous increase $\left(X_{t}^{+}\right)$. Besides that $\alpha_{11}^{-}$capture the long-run relation between unemployment rate and its exogenous reduction, $\left(X_{t}^{-}\right)$.

Shin et al. (2011) established that the asymmetric effect of exogenous variable on the endogenous variable exists if the magnitude of exogenous increase of such variable has a significant different than the magnitude of exogenous reduction of the variable. Where the findings display $\alpha_{11}^{+}=\alpha_{11}^{-}$then the asymmetric pass-through effects from core variables (globalization indicators and technological innovation indicators) to unemployment rate will not exist. Essentially, the equation (3) is extended as shown in Shin et al. (2011) which can be framed in an ARDL setting along the line of Pesaran and Shin (1999) and Pesaran et al. (2001) as:

$$
\begin{aligned}
& U M_{t}=\gamma_{0} U_{t-1}+\gamma_{1}^{+} X_{t-1}^{+}+\gamma_{1}^{+} X_{t-1}^{+}+\gamma_{7} C_{t-1}+\sum_{j=1}^{p-1} \theta_{1} \Delta U_{t-j}+\sum_{j=0}^{q-1}\left(\beta_{j}^{+} \Delta X_{t-j}^{+}+\beta_{t-j}^{-} \Delta X_{t-j}^{-}\right)
\end{aligned}
$$

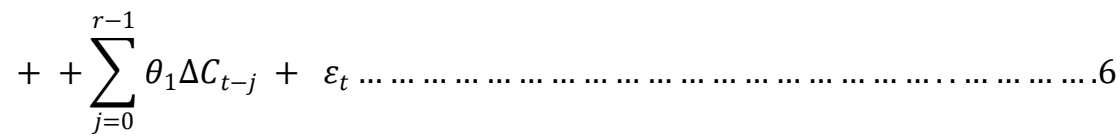

where $\Delta$ indicates the first difference and $\rho-1, \mathrm{q}-1$ and $\mathrm{r}-1$ are the lag lengths. Equation (6) is the empirical model the study tends to estimate the long run relationship between the candidate variables; globalization (trade openness and financial openness), technological innovation (process innovation and product innovation) and independent variable, unemployment rate.

Based on the assumption of linearity and this study introduces the possibility of nonlinearity in modeling the relationship. Since all parameters contained in equation (6) are linear which allows estimation of model using standard ordinary least square (OLS) method. The unrestricted specification of NARDL error correction model in equation (6) proclaims to have two different types of asymmetry; short and long-run asymmetries. To gauge both long-run and short-run asymmetric tests, we run the Wald test. (See Shin, et al., 2011). The long-run nonlinearity model with the null hypothesis of a linear long run relationship is tested through $\gamma_{1}^{+} \delta^{+}=\gamma_{1}^{-}$while the short-run 
nonlinearity model in which the null hypothesis of additive linearity is tested through $\sum_{j=0}^{p-1} \beta_{j}^{+}=\sum_{j=0}^{p-1} \beta_{j}^{-}$. According to Shin et al.(2014), long-run co-integration with the aid of estimated NARDL can be confirmed using the bounds test approach applicable by comparing the f-statistic (Wald test) and the critical value, as proposed by Pesaran et al. (2001). The null hypothesis is $0 \gamma_{0}=\gamma_{1}^{+}=\gamma_{1}^{+}=\gamma_{7}=0$.

To further assess the relationship between globalization, technological innovation and unemployment rate, we carry out granger causality test based on error correction model. The Granger causality based on error correction model guides us not only to know the direction of causation but also to identify the variables that are exogenous and endogenous including the lagged ECM. This lagged ECM would be informing us how it takes to revert back to equilibrium when there is shock to the variable. In addition, the study also adopts the variance decompositions (VDC) where information on the relative degree of endogeneity and exogeneity of the variables are to be obtained.

\subsection{Data Definition and Sources}

The study has been carried out using quarterly data over the period from 2000Q1 to 2018Q4. These periods are set due to the fact that some of the data got reported in 2000, and they are annual data, which were converted into quarterly data using an E-Views package for analysis. The data related to trade globalization, financial globalization, unemployment, inflation and income inequality were sourced from World Development Indicators whereas data relating to product innovation obtained from Economic Research, Federal Reserve Bank of St. Louis, while process innovation data related sourced from Nigeria Communication Commission.

\section{Results}

Although NARDL does not require a data pretesting before estimation of the data using NARDL, this study's author decided to determine the order of integration of all the data. The table 1 below shows the results of the Augmented Dickey-Fuller (ADF) unit root tests for the order of integration of the variables under investigation. The results of the Augmented Dickey-Fuller (ADF) unit root test conducted to determine the stationarity properties of selected variables considering the intercept without the trend properties, the outcome of the results indicated that, with the exception of technological innovation indicators, all other variables are not characterized by the unit root at level, whereas all the variables revealed evidence of stationarity at first difference, mostly at a 5 percent significance level. The conclusion is that all the variables are integrated of order 1, which lend support to the use of NARDL.

Table 1. Unit Root Test Results (ADF Test)

\begin{tabular}{|c|c|c|c|c|c|c|c|}
\hline Variables & TG & FG & RI & II & $G$ & INF & UM \\
\hline Level & -1.974 & -0.174 & -2.023 & -2.043 & -0.401 & -3.140 & -1.404 \\
\hline $1^{\text {st }} \quad$ Diff. & -2.296 & -2.852 & -3.700 & -3.688 & -2.295 & -4.412 & -2.394 \\
\hline
\end{tabular}

After establishing the order of integration of each variable, the next is to estimate the NARDL model by testing for asymmetric co-integration via F statistical test that employed the Wald test. As for F-test, the null hypothesis of no co-integration had been tested for the model. The results are as tabulated in Table 2 indicating that the Fstatistics for the model was larger than the upper bound and the lower bound values of $1 \%$ significant level. Hence, the null hypothesis of no co-integration is rejected, thus verifying the presence of long run co-integration in all model.

Table 2. Bound Test for Asymmetric Co integration

\begin{tabular}{cll}
\hline F- statistic & & 13.21 \\
\hline Critical values for F-statistics & Lower $\mathrm{I}(0)$ & Upper $\mathrm{I}(0)$ \\
$10 \%$ & 1.83 & 2.94 \\
$5 \%$ & 2.06 & 3.24 \\
$1 \%$ & 2.54 & 3.81 \\
\hline
\end{tabular}




\subsection{Non-Linear Estimation Result}

As regards the evidence of cointegration relationship between the analyzed variables, it is of our interest to conduct the existence of an asymmetric relationship between trade globalization, financial globalization, process innovation, product innovation, inflation, income inequality and dependent variable, unemployment of Nigeria by using equation (11) based on Non-linear ARDL model proposed by Shin et al. (2014). Table 3 displays the NARDL estimations which are in four parts. Table $3 \mathrm{c}$ reports the model residual diagnostic test which include test of Autocorrelation, a test of heteroscedasticity and the RESET test, confirming model estimation robustness and stability. The outcomes of these residual diagnostic tests indicate that the Test of Autocorrelation estimation confirms free from serial correlation, and test of Heteroscedasticity ascertains that there is no ARCH effects. On the other hand, the RESET test confirms model construction validity of this study and the coefficient of adjusted $\mathrm{R}^{2}$ explains the model capability, whose coefficient is significantly high with 75 percent. In addition, Figure 1 and 2 represent CUSUM and CUSUMSQ tests of this model. The figures show that our model passed the CUSUM test whereas the CUSUMQ graph has shown that our model deviated from the test as the significant lines crossed the critical lines. This implies instability in the model. This could be characterized to be as sample covered a period of episodes of economic recession including genesis of information technology in Nigeria.

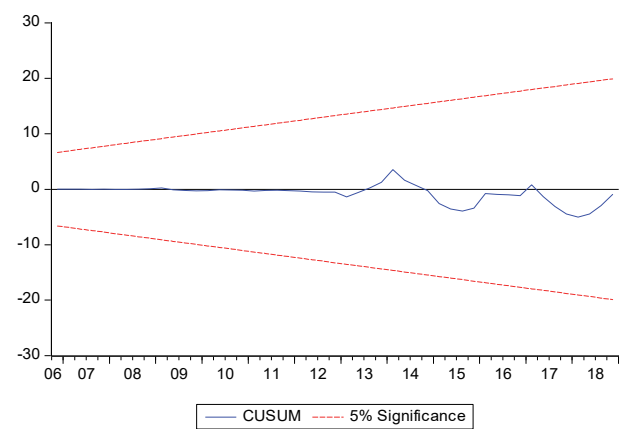

Figure 1.

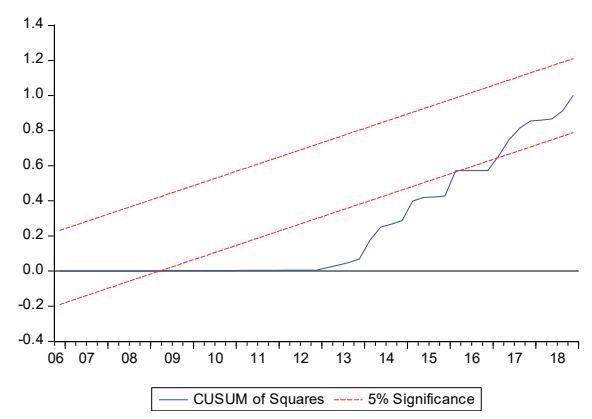

Figure 2.

In the long-run, table 3a shows that the positive shock in trade globalization reveals positive coefficient with statistically significant. This implies that any positive development in trade globalization promotes long-run unemployment growth in this economy. On the other hand, we observe a negative shock of trade globalization negatively associated with the unemployment growth. For financial globalization, the positive shock shows negative sign of coefficient with statistical insignificance indicating that the financial globalization decreases the magnitude of the unemployment rate while its negative shock shows a positive and significant relationship with the unemployment rate in the long-run. With regard to process innovation, the positive shock reduces the size of unemployment without statistical significance whereas its negative shock increases the unemployment rate at ten significance level. In case of product innovation recording significant impact in both shocks, the study discovers that a positive shock brings a negative change in the unemployment rate, whereas, its negative shock dampens the rate of unemployment in the economy. In the long-run, whether the differences in the positive and negative coefficients of the candidate variables of interest - trade globalization, financial globalization, product innovation and process innovation are significantly different, the Wald symmetric tests are used to determine them. In addition, coefficient of inflation rate is positive and significant at ten percent significance level. It implies that a one percent increase in inflation rate in the economy heightens the level of unemployment by 0.01 percent whereas income inequality also shows a positive and significant impact on the unemployment rate at one percent significance level. A one percent rise in income inequality escalates the unemployment rate by 0.058 percent in this economy.

The short-run estimation is indicated in Table $3 b$, where a positive effect of trade globalization shows a positive relationship with the unemployment rate whereas the negative effect of trade globalization ensures reduction in the rate of unemployment. The positive and negative effects of the financial globalization increase the size of unemployment rate which are statistically significant. From the process innovation, its positive effect has direct impact on the unemployment rate whereas its negative effect records a negative relationship with the unemployment rate while both positive and negative effects of product innovation on the unemployment rate indicate negative relationships i.e. the unemployment rate reduces when there are positive and negative shocks. The Wald symmetric tests are also explored in determining whether the differences in the positive and negative coefficients of the variables trade globalization, financial globalization, product innovation and process innovation are significantly different in the short run. 
Moreover, the long run relationship outcomes in table 4 revealed both positive and negative shocks of product innovation and trade globalization influenced the unemployment rate; they were significant for at least $10 \%$ significant level. With the varying coefficient values detected, the non-linear estimation result is confirmed. The Positive shock of process innovation impacted the unemployment rate whereas negative shock of financial globalization influenced the unemployment rate were significant for one percent and ten percent significant level respectively. Given that the positive and negative components of process innovation and financial globalization's coefficients for size differed which is confirmed via the non-linear estimation result. The next is to analyze asymmetric association via asymmetric test (Wald test).

Table $3 \mathrm{~d}$ indicates the asymmetric impact in the long and short run examined by the Wald test via checking the null hypothesis of symmetry against the alternative of as asymmetry. The results presented in the table $3 \mathrm{~d}$ shows the significance of asymmetry in the short-run, variables like trade globalization, product innovation and product innovation are detected to adjust at one percent significance level except the financial globalization whose adjustment detected at ten percent significance level. There is also significance of asymmetry in the long-run with respect to product innovation and process innovation at one percent significance level adjustment when the trade openness and financial openness adjusted at ten percent significance level each. This implies that taking the nonlinearity and asymmetry into account is important both in the short and long run when analyzing the relationship between globalization indicators, technological innovation indicators and unemployment rate.

Table 3. Non-Linear Estimation Results

\begin{tabular}{lccl}
\hline \multicolumn{4}{c}{ Table 3a. Short-Run } \\
\hline Variables & coefficient & t-statistic & Probability \\
$\Delta \mathrm{TG}^{+}$ & 0.003 & 0.265 & 0.7922 \\
$\Delta \mathrm{TG}^{+}(\mathrm{t}-1)$ & -0.025 & -2.127 & $0.0384^{*}$ \\
$\Delta \mathrm{TG}^{(\mathrm{t}-2)}$ & -0.022 & -1.832 & $0.0729^{*}$ \\
$\Delta \mathrm{TG}^{-}$ & 0.056 & 4.446 & $0.0000^{* * *}$ \\
$\Delta \mathrm{FG}^{+}$ & 0.623 & 3.799 & $0.0004^{* * *}$ \\
$\Delta \mathrm{FG}^{-}$ & 0.437 & 2.933 & $0.0051^{* *}$ \\
$\Delta(\operatorname{logII})^{+}$ & 0.035 & 1.071 & 0.2889 \\
$\Delta(\operatorname{logII})^{-}$ & -0.059 & -1.322 & $0.1920^{*}$ \\
$\Delta \mathrm{RI}^{+}$ & -12.19 & -4.817 & $0.0000^{* * *}$ \\
$\Delta \mathrm{RI}^{-}$ & -8.555 & -5.959 & $0.0000^{* * *}$ \\
\hline
\end{tabular}

\begin{tabular}{cccl}
\hline \multicolumn{3}{c}{ Table 3b. Long-Run } \\
\hline Variables & Coefficients & t-statistic & probability \\
$\mathrm{C}$ & -1.499 & -1.866 & $0.0670^{*}$ \\
$\mathrm{TG}^{+}(\mathrm{t}-1)$ & 0.020 & 1.872 & $0.0680^{*}$ \\
$\mathrm{TG}_{(\mathrm{t}-1)}$ & -0.015 & -2.877 & $0.0059^{* *}$ \\
$\mathrm{FG}_{(\mathrm{t}-1}^{+}$ & -0.007 & -0.067 & 0.9468 \\
$\mathrm{FG}_{(\mathrm{t}-1)}^{-}$ & 0.227 & 2.530 & $0.0149^{*}$ \\
$\log (\mathrm{II})^{+}(\mathrm{t}-1)$ & -0.018 & -1.005 & 0.3198 \\
$\log (\mathrm{II})^{-}(\mathrm{t}-1)$ & 0.043 & 1.981 & $0.0531^{*}$ \\
$\mathrm{RI}_{(\mathrm{t}-1)}$ & -1.985 & -1.819 & $0.0749^{*}$ \\
$\mathrm{RI}_{(\mathrm{t}-1)}$ & 2.084 & 2.779 & $0.0026^{* *}$ \\
$\mathrm{G}_{(\mathrm{t}-1)}$ & 0.058 & 5.213 & $0.0000^{* * *}$ \\
$\log (\mathrm{INF})$ & 0.014 & 1.822 & $0.0744^{*}$ \\
\hline
\end{tabular}




\begin{tabular}{|c|c|c|}
\hline $\mathrm{UM}_{(\mathrm{t}-1)}$ & -2.898 & $0.0056^{* *}$ \\
\hline \multicolumn{3}{|c|}{ Table 3c. Diagnostic Test } \\
\hline Serial correlation (LM) Test & $3.24(0.04)$ & \\
\hline Heteroskedasticity Test (BPG) & $1.97(0.024)$ & \\
\hline RESET Test & $2.71(0.10)$ & \\
\hline Adjusted $\mathrm{R}^{2}$ & 0.75 & \\
\hline
\end{tabular}

\begin{tabular}{|c|c|c|c|}
\hline \multicolumn{4}{|c|}{ Table 3d. Asymmetric Test } \\
\hline \multicolumn{2}{|c|}{ Short-Run Wald Test } & \multicolumn{2}{|c|}{ Long-Run Wald Test } \\
\hline $\mathrm{TG}_{\mathrm{SR}}$ & $34.0(0.0000)$ & $\mathrm{TG}_{\mathrm{LR}}$ & $1.9(0.1717)$ \\
\hline $\mathrm{FG}_{\mathrm{SR}}$ & $5.3(0.0261)$ & $\mathrm{FG}_{\mathrm{LR}}$ & $2.4(0.1284)$ \\
\hline $\mathrm{II}_{\mathrm{SR}}$ & $26.0(0.0000)$ & $\mathrm{II}_{\mathrm{LR}}$ & $34.9(0.0000)$ \\
\hline $\mathrm{RI}_{\mathrm{SR}}$ & $29.0(0.0000)$ & $\mathrm{RI}_{\mathrm{LR}}$ & $53.5(0.0000)$ \\
\hline
\end{tabular}

Table 4. Long Run Relationship

\begin{tabular}{|c|c|c|c|}
\hline Variable & Coefficient & t-Statistic & Prob. \\
\hline RI_POS $(-1)$ & -5.126975 & -2.948428 & $0.0045^{* *}$ \\
\hline RI_NEG $(-1)$ & 4.958363 & 1.876338 & $0.0652^{*}$ \\
\hline $\log (\mathrm{II}) \mathrm{NEG}_{(-1)}$ & -0.079458 & -0.754528 & 0.4533 \\
\hline $\log (\mathrm{II}){ }_{1} \mathrm{POS}_{(-1)}$ & -0.284945 & -3.740653 & $0.0004 * * *$ \\
\hline $\mathrm{FG}_{-} \mathrm{NEG}_{(-1)}$ & 0.648923 & 1.510638 & $0.1359^{*}$ \\
\hline FG_POS $_{(-1)}$ & -0.098537 & -0.317510 & 0.7519 \\
\hline TG_NEG $_{(-1)}$ & -0.116975 & -5.501425 & $0.0000^{* * *}$ \\
\hline TG_POS $(-1)$ & 0.125967 & 3.242414 & $0.0019 * *$ \\
\hline $\mathrm{G}(-1)$ & 0.044383 & 2.930193 & $0.0047 * *$ \\
\hline $\log (\operatorname{INF})_{(-1)}$ & 0.217379 & 7.548008 & $0.0000 * * *$ \\
\hline
\end{tabular}

Note: $(*),(* *)$, and $(* * *)$ indicate $10 \%, 5 \%$ and $1 \%$ significance level respectively

\subsection{Granger Causality Test Results}

The existence of cointegration between globalization indicators (trade and financial), technological innovation indicators (product and process innovation), control variables (income inequality and inflation) and unemployment induce to deepen our investigation into the directional influence among the candidate variables of study. To assess the direction of causality, the paper conducts the Granger causality test based on error correction model. The Granger causality in the vector error correction mechanism is used to verify the directions of causality between the aforementioned indicators as well as to decompose the directions of causality into the short- and the long-run effects. The study conducted short-run causality tests using the p-values and test for the significance of the lagged error-correction terms, $\mathrm{ECM}_{\mathrm{t}-1}$, in order to establish the long-run causality between the explanatory variables and the dependent variable, using the t-test error correction model. The study found some long-run causal relationship, especially when the unemployment rate considers as the dependent variable in the equation, which confirms the existence of long-run causality between the globalization indicators (trade and financial), technological innovation indicators (product and process innovation), control variables (income inequality and inflation) and the unemployment rate in Nigeria.

In the short run causal relationship, the evidence of a unidirectional causality relationship exists running from between process innovation to unemployment whereas a bidirectional causal relation was detected between 
product innovation and unemployment. Apart from that, the study revealed a bidirectional causality between the trade globalization and the unemployment rate including financial globalization and unemployment. Moreover, our findings discovered a bidirectional causal relationship between inflation rate and unemployment rate as well as between income inequality and unemployment rate.

To this end, the study generates the variance decompositions of the variables as error correction could display the absolute exogeneity or endogeneity whereas it could not display the relative endogeneity and exogeneity. The results from the Generalized VDCs are as shown in Table 6 (a-g). The variable that is ranked higher is the leading variable, and therefore should be set as the immediate target by the policymakers. The results in table for the 20 years horizon, trade openness is the most exogenous which all through the 20-years horizon, own shock accounts for over 87 per cent while income inequality is shown to be the most endogenous as its own shock reached 81.25 per cent in the 20th period. Most importantly, when the unemployment rate serves as dependent variable, variation in unemployment rate is contributed by its own past, product innovation, inflation, financial openness and trade openness whereas process innovation had minor significant impact. In short-run, its own past innovation, product innovation, inflation, financial and trade openness played important roles while income inequality, its past contribution, product innovation, inflation rate, trade and financial had contributed significant impact more on the long-run.

Table 5. Granger Causality Results

\begin{tabular}{|c|c|c|c|c|c|c|c|c|}
\hline Variables & $\Delta \mathrm{UM}$ & $\Delta \mathrm{FG}$ & $\Delta \mathrm{TG}$ & $\Delta(\log I I)$ & $\Delta \mathrm{RI}$ & $\Delta \mathrm{G}$ & $\Delta(\log I N F)$ & ECM \\
\hline$\Delta \mathrm{UM}$ & - & $\begin{array}{l}5.1 \\
(0.023)^{*}\end{array}$ & $\begin{array}{l}8.15 \\
(0.004)^{* *}\end{array}$ & $\begin{array}{l}4.76 \\
(0.029)^{*}\end{array}$ & $\begin{array}{l}16.5 \\
(0.000)^{* * *}\end{array}$ & $\begin{array}{l}18.4 \\
0 .(000) * * *\end{array}$ & $\begin{array}{l}6.9 \\
(0.008)^{* * *}\end{array}$ & $\begin{array}{l}-0.07 \\
(-3.50)^{* * *}\end{array}$ \\
\hline$\Delta \mathrm{FG}$ & $\begin{array}{l}6.16 \\
(0.013)^{*}\end{array}$ & - & $\begin{array}{l}0.36 \\
(0.550)\end{array}$ & $\begin{array}{l}2.37 \\
(0.124)\end{array}$ & $\begin{array}{l}8.01 \\
(0.005)^{* *}\end{array}$ & $\begin{array}{l}4.11 \\
(0.043)^{*}\end{array}$ & $\begin{array}{l}1.92 \\
(0.166)^{*}\end{array}$ & $\begin{array}{l}-0.08 \\
(-1.41)^{*}\end{array}$ \\
\hline$\Delta \mathrm{TG}$ & $\begin{array}{l}18.02 \\
(0.000)^{* * *}\end{array}$ & $\begin{array}{l}6.01 \\
(0.014)^{*}\end{array}$ & - & $\begin{array}{l}0.64 \\
(0.423)\end{array}$ & $\begin{array}{l}3.34 \\
(0.068)^{*}\end{array}$ & $\begin{array}{l}0.55 \\
(0.458)\end{array}$ & $\begin{array}{l}0.01 \\
(0.931)\end{array}$ & $\begin{array}{l}-0.02 \\
(-0.44)\end{array}$ \\
\hline$\Delta(\log I I)$ & $\begin{array}{l}0.11 \\
(0.739)\end{array}$ & $\begin{array}{l}7.65 \\
(0.006)^{* *}\end{array}$ & $\begin{array}{l}1.06 \\
(0.304)\end{array}$ & - & $\begin{array}{l}1.11 \\
(0.290)\end{array}$ & $\begin{array}{l}2.24 \\
(0.134)^{*}\end{array}$ & $\begin{array}{l}20.63 \\
(0.000)^{* * *}\end{array}$ & $\begin{array}{l}-0.99 \\
(-1.73)^{*}\end{array}$ \\
\hline$\Delta \mathrm{RI}$ & $\begin{array}{l}16.54 \\
(0.000)^{* * *}\end{array}$ & $\begin{array}{l}8.76 \\
(0.003)^{* *}\end{array}$ & $\begin{array}{l}7.30 \\
(0.007)^{* *}\end{array}$ & $\begin{array}{l}11.23 \\
(0.001)^{* *}\end{array}$ & - & $\begin{array}{l}22.66 \\
(0.000)^{* * *}\end{array}$ & $\begin{array}{l}2.41 \\
(0.121)^{*}\end{array}$ & $\begin{array}{l}-0.08 \\
(-3.07)^{*}\end{array}$ \\
\hline$\Delta \mathrm{G}$ & $\begin{array}{l}3.75 \\
(0.053)^{*}\end{array}$ & $\begin{array}{l}2.39 \\
(0.122)^{*}\end{array}$ & $\begin{array}{l}13.93 \\
(0.000)^{* * *}\end{array}$ & $\begin{array}{l}2.16 \\
(0.141)^{*}\end{array}$ & $\begin{array}{l}1.83 \\
(0.176)\end{array}$ & - & $\begin{array}{l}0.85 \\
(0.357)\end{array}$ & $\begin{array}{l}0.01 \\
(3.82)^{* * *}\end{array}$ \\
\hline$\Delta(\log I N F)$ & $\begin{array}{l}10.60 \\
(0.001)^{* *}\end{array}$ & $\begin{array}{l}0.01 \\
(0.971)\end{array}$ & $\begin{array}{l}0.549 \\
(0.459)\end{array}$ & $\begin{array}{l}23.14 \\
(0.000)^{* * *}\end{array}$ & $\begin{array}{l}4.19 \\
(0.041)^{*}\end{array}$ & $\begin{array}{l}4.88 \\
(0.027)^{*}\end{array}$ & - & $\begin{array}{l}-0.10 \\
(-2.33)^{* *}\end{array}$ \\
\hline
\end{tabular}

Note: $(*),(* *)$, and $(* * *)$ indicate $10 \%, 5 \%$ and $1 \%$ significance level respectively

Table 6. Variance Decomposition

(a)Variance Decomposition of Trade Globalization

\begin{tabular}{cccccccc}
\hline Period & $\Delta \mathrm{TG}$ & $\Delta \mathrm{FG}$ & $\Delta(\operatorname{logII})$ & $\Delta(\operatorname{logINF})$ & $\Delta \mathrm{RI}$ & $\Delta \mathrm{UM}$ & $\Delta \mathrm{G}$ \\
\hline 1 & 100.0000 & 0.000000 & 0.000000 & 0.000000 & 0.000000 & 0.000000 & 0.000000 \\
2 & 99.38532 & 0.120278 & 0.417875 & 0.012702 & 0.040090 & 0.020059 & 0.003676 \\
3 & 97.54721 & 0.617625 & 1.566381 & 0.081064 & 0.134688 & 0.036648 & 0.016388 \\
4 & 95.16236 & 1.313906 & 2.963608 & 0.219129 & 0.266825 & 0.034382 & 0.039795 \\
5 & 93.16310 & 1.862796 & 4.065274 & 0.394493 & 0.415415 & 0.025448 & 0.073471 \\
15 & 89.08471 & 1.794941 & 5.263405 & 1.385561 & 1.336187 & 0.020613 & 1.114577 \\
16 & 88.79663 & 1.760884 & 5.279722 & 1.461768 & 1.378798 & 0.023644 & 1.298550 \\
17 & 88.50825 & 1.726799 & 5.291133 & 1.536390 & 1.415587 & 0.026979 & 1.494859 \\
18 & 88.21595 & 1.693850 & 5.300361 & 1.609821 & 1.447113 & 0.030511 & 1.702391 \\
\hline
\end{tabular}




\begin{tabular}{llllllll}
\hline 19 & 87.91880 & 1.662420 & 5.308509 & 1.682344 & 1.473910 & 0.034101 & 1.919919 \\
20 & 87.61782 & 1.632352 & 5.315557 & 1.754029 & 1.496464 & 0.037625 & 2.146150 \\
\hline
\end{tabular}

(b)Variance Decomposition of Financial Globalization

\begin{tabular}{cccccccc}
\hline Period & $\Delta \mathrm{TG}$ & $\Delta \mathrm{FG}$ & $\Delta(\log \mathrm{II})$ & $\Delta(\log \mathrm{INF})$ & $\Delta \mathrm{RI}$ & $\Delta \mathrm{UM}$ & $\Delta \mathrm{G}$ \\
\hline 1 & 4.723440 & 95.27656 & 0.000000 & 0.000000 & 0.000000 & 0.000000 & 0.000000 \\
2 & 5.254361 & 93.02779 & 1.557347 & 0.033939 & 0.004304 & 0.121238 & 0.001017 \\
3 & 5.754224 & 86.55878 & 7.150842 & 0.294349 & 0.005486 & 0.230593 & 0.005728 \\
4 & 5.788086 & 77.53327 & 15.51691 & 0.933109 & 0.003907 & 0.211328 & 0.013391 \\
5 & 5.416650 & 69.44801 & 23.13266 & 1.815958 & 0.004518 & 0.162650 & 0.019559 \\
15 & 3.066184 & 57.51884 & 33.77720 & 4.548838 & 0.015679 & 0.911278 & 0.161973 \\
16 & 3.030570 & 57.23937 & 33.95006 & 4.556734 & 0.018963 & 0.979990 & 0.224313 \\
17 & 3.008539 & 57.00125 & 34.07584 & 4.547314 & 0.022580 & 1.044552 & 0.299917 \\
18 & 2.998500 & 56.77905 & 34.17715 & 4.525087 & 0.026388 & 1.104876 & 0.388952 \\
19 & 2.998449 & 56.56064 & 34.26415 & 4.493559 & 0.030241 & 1.161592 & 0.491371 \\
20 & 3.006441 & 56.34443 & 34.33781 & 4.454987 & 0.034023 & 1.215348 & 0.606966 \\
\hline
\end{tabular}

(c)Variance Decomposition of Process Innovation

\begin{tabular}{cccccccc}
\hline Period & $\Delta \mathrm{TG}$ & $\Delta \mathrm{FG}$ & $\Delta(\log \mathrm{II})$ & $\Delta(\operatorname{logINF})$ & $\Delta \mathrm{RI}$ & $\Delta \mathrm{UM}$ & $\Delta \mathrm{G}$ \\
\hline 1 & 1.289446 & 4.151886 & 94.55867 & 0.000000 & 0.000000 & 0.000000 & 0.000000 \\
2 & 0.518550 & 1.697690 & 97.07674 & 0.005631 & 0.059318 & 0.634574 & 0.007496 \\
3 & 0.732504 & 4.845126 & 92.52821 & 0.045688 & 0.165651 & 1.640089 & 0.042732 \\
4 & 1.237313 & 14.68410 & 81.19248 & 0.368867 & 0.257585 & 2.149691 & 0.109966 \\
5 & 1.524863 & 25.04002 & 69.91174 & 0.959872 & 0.317295 & 2.058796 & 0.187414 \\
15 & 1.780098 & 37.07345 & 56.67160 & 2.213074 & 1.260394 & 0.697282 & 0.304103 \\
16 & 1.813776 & 37.27492 & 56.43325 & 2.193961 & 1.349489 & 0.649924 & 0.284681 \\
17 & 1.849853 & 37.42663 & 56.24714 & 2.166856 & 1.434727 & 0.608322 & 0.266477 \\
18 & 1.888967 & 37.56222 & 56.07598 & 2.134522 & 1.515745 & 0.571574 & 0.250990 \\
19 & 1.930571 & 37.69534 & 55.90451 & 2.099024 & 1.592118 & 0.538953 & 0.239484 \\
20 & 1.973803 & 37.82461 & 55.73360 & 2.061461 & 1.663612 & 0.509899 & 0.233015 \\
\hline
\end{tabular}

(d)Variance Decomposition of Inflation Rate

\begin{tabular}{cccccccc}
\hline Period & $\Delta \mathrm{TG}$ & $\Delta \mathrm{FG}$ & $\Delta(\operatorname{logII})$ & $\Delta(\operatorname{logINF})$ & $\Delta \mathrm{RI}$ & $\Delta \mathrm{UM}$ & $\Delta \mathrm{G}$ \\
\hline 1 & 3.816809 & 7.936221 & 15.34044 & 72.90653 & 0.000000 & 0.000000 & 0.000000 \\
2 & 1.728166 & 9.060436 & 11.81967 & 77.31315 & 0.014141 & 0.000176 & 0.064263 \\
3 & 0.853959 & 10.98540 & 8.729724 & 79.11595 & 0.047377 & 0.007148 & 0.260439 \\
4 & 0.538377 & 12.87250 & 6.527843 & 79.27799 & 0.094747 & 0.061580 & 0.626967 \\
5 & 0.461889 & 14.14759 & 5.126754 & 78.71145 & 0.154238 & 0.198649 & 1.199435 \\
15 & 1.887413 & 10.81032 & 2.673579 & 65.14202 & 0.855033 & 2.053041 & 16.57859 \\
16 & 2.061205 & 10.40030 & 2.602508 & 63.49282 & 0.876357 & 2.122974 & 18.44384 \\
17 & 2.229898 & 10.00853 & 2.539809 & 61.89296 & 0.888492 & 2.173290 & 20.26702 \\
\hline
\end{tabular}




\begin{tabular}{llllllll}
\hline 18 & 2.392838 & 9.638290 & 2.483116 & 60.35181 & 0.892655 & 2.206356 & 22.03494 \\
19 & 2.549377 & 9.290707 & 2.431138 & 58.87581 & 0.890055 & 2.224756 & 23.73816 \\
20 & 2.699007 & 8.965328 & 2.383342 & 57.46918 & 0.881851 & 2.230921 & 25.37037 \\
\hline
\end{tabular}

(e) Variance Decomposition of Product Innovation

\begin{tabular}{cccccccc}
\hline Period & $\Delta \mathrm{TG}$ & $\Delta \mathrm{FG}$ & $\Delta(\log \mathrm{II})$ & $\Delta(\log \mathrm{INF})$ & $\Delta \mathrm{RI}$ & $\Delta \mathrm{UM}$ & $\Delta \mathrm{G}$ \\
\hline 1 & 15.30599 & 18.15627 & 0.042131 & 0.364619 & 66.13099 & 0.000000 & 0.000000 \\
2 & 14.37603 & 13.71956 & 0.078551 & 0.236561 & 71.00879 & 0.499847 & 0.080667 \\
3 & 13.12117 & 10.12771 & 0.432720 & 0.117247 & 74.35655 & 1.464651 & 0.379943 \\
4 & 11.59268 & 7.634779 & 0.886010 & 0.091128 & 76.22146 & 2.580304 & 0.993644 \\
5 & 9.985480 & 6.061231 & 1.209326 & 0.175826 & 76.88369 & 3.698045 & 1.986399 \\
15 & 1.597828 & 2.936201 & 1.228958 & 3.517304 & 52.64806 & 9.948992 & 28.12266 \\
16 & 1.394590 & 2.815229 & 1.229108 & 3.898959 & 49.66461 & 9.926288 & 31.07122 \\
17 & 1.252497 & 2.705365 & 1.229242 & 4.262185 & 46.82427 & 9.836292 & 33.89015 \\
18 & 1.160482 & 2.604548 & 1.229830 & 4.605256 & 44.14281 & 9.694152 & 36.56292 \\
19 & 1.109002 & 2.511612 & 1.230909 & 4.927357 & 41.62800 & 9.512677 & 39.08044 \\
20 & 1.089948 & 2.425939 & 1.232256 & 5.228250 & 39.28148 & 9.302666 & 41.43946 \\
\hline
\end{tabular}

(f) Variance Decomposition of Unemployment Rate

\begin{tabular}{cccccccc}
\hline Period & $\Delta \mathrm{TG}$ & \multicolumn{1}{l}{$\Delta \mathrm{FG}$} & $\Delta(\operatorname{logII})$ & $\Delta(\operatorname{logINF})$ & $\Delta \mathrm{RI}$ & \multicolumn{1}{l}{$\Delta \mathrm{UM}$} & $\Delta \mathrm{G}$ \\
\hline 1 & 3.933360 & 4.138335 & 0.025638 & 3.978308 & 47.75361 & 40.17075 & 0.000000 \\
2 & 2.246945 & 4.475393 & 0.008865 & 4.719875 & 46.47828 & 41.91960 & 0.151037 \\
3 & 1.319501 & 4.831318 & 0.004917 & 5.387294 & 44.57087 & 43.29846 & 0.587640 \\
4 & 0.813976 & 5.087179 & 0.003774 & 6.028056 & 42.32913 & 44.38425 & 1.353636 \\
5 & 0.553965 & 5.203675 & 0.002705 & 6.671398 & 39.93503 & 45.16058 & 2.472655 \\
15 & 1.700337 & 4.182600 & 0.220711 & 11.70926 & 19.53059 & 37.32311 & 25.33339 \\
16 & 1.893581 & 4.062602 & 0.246608 & 11.96073 & 18.22112 & 35.91432 & 27.70104 \\
17 & 2.081639 & 3.946102 & 0.271609 & 12.17700 & 17.03834 & 34.52849 & 29.95681 \\
18 & 2.263061 & 3.834200 & 0.295459 & 12.36207 & 15.97225 & 33.18079 & 32.09216 \\
19 & 2.436847 & 3.727441 & 0.318062 & 12.51976 & 15.01266 & 31.88199 & 34.10324 \\
20 & 2.602391 & 3.626023 & 0.339420 & 12.65367 & 14.14958 & 30.63918 & 35.98974 \\
\hline
\end{tabular}

(g) Variance Decomposition of Income Inequality

\begin{tabular}{cccccccc}
\hline Period & $\Delta \mathrm{TG}$ & $\Delta \mathrm{FG}$ & $\Delta(\log \mathrm{II})$ & $\Delta(\operatorname{logINF})$ & $\Delta \mathrm{RI}$ & $\Delta \mathrm{UM}$ & $\Delta \mathrm{G}$ \\
\hline 1 & 0.013515 & 3.250956 & 0.017533 & 21.24652 & 3.086302 & 3.212985 & 69.17219 \\
2 & 0.437009 & 1.341902 & 0.085170 & 19.36163 & 2.611982 & 3.077140 & 73.08517 \\
3 & 1.009566 & 0.527142 & 0.158088 & 17.61191 & 2.213163 & 3.021949 & 75.45818 \\
4 & 1.546568 & 0.264757 & 0.173812 & 16.17167 & 1.883180 & 3.004775 & 76.95524 \\
5 & 2.005336 & 0.202185 & 0.137806 & 15.08312 & 1.615768 & 2.981376 & 77.97441 \\
15 & 4.482700 & 0.242580 & 0.159609 & 12.01099 & 0.484721 & 1.747085 & 80.87232 \\
16 & 4.611005 & 0.250312 & 0.178333 & 11.91552 & 0.435042 & 1.643857 & 80.96593 \\
\hline
\end{tabular}




\begin{tabular}{rlllllll}
\hline 17 & 4.727055 & 0.257118 & 0.196332 & 11.83182 & 0.390951 & 1.548198 & 81.04852 \\
18 & 4.832403 & 0.263213 & 0.213371 & 11.75775 & 0.351799 & 1.459624 & 81.12184 \\
19 & 4.928290 & 0.268709 & 0.229371 & 11.69165 & 0.317025 & 1.377670 & 81.18728 \\
20 & 5.015759 & 0.273652 & 0.244353 & 11.63229 & 0.286143 & 1.301863 & 81.24594 \\
\hline
\end{tabular}

\subsection{Discussion of Results}

The evidence presented in this article suggests that a long-run relationship exist between the variables interest of study, such as globalization variables and technological innovation variables. Empirical findings unveiled the longrun nexus to some extent, digressing from the expectation based on the economic theory.

The increase in trade globalization bore positive sign indicating a positive relationship with unemployment rate. This suggests that Nigeria is a highly import-consuming nation that fails to establish an effective and efficient import substitution policy. This outcome is not consistent with the H-O theory expecting inverse relationship between trade globalization and unemployment rate in labour abundant society. This study agreed with empirical findings of Rafiu (2017) and Raji (2019) when similar studies were conducted. The decrease in trade globalization is negatively and significantly related to the unemployment rate. It implies that negative shocks in trade openness mitigates the magnitude of unemployment growth. This could be attributed to higher trade exposure or increase in the use capital intensive method of production or both.

The decrease in financial globalization tends to escalate size of the unemployment rate significantly whereas the increase in financial globalization is negatively and insignificantly related to unemployment rate which is in support of Johnny et al. (2018). This implies that there are some key sectors in the economy that are yet to receive considerable attention of foreign direct investment or government policy/measures which lack significant effect on the inward financial globalization (FDI) in this economy, which could enhance economic growth more than the present situation and boost employment rate.

The short-run increase and decrease of process innovation are directly related to unemployment. Its negative shock reported fall in the unemployment rate with significant impact and its positive shock is insignificantly related to unemployment. This estimate related to Orji et al.( 2016), who realized that process innovation proxied by ICT had a direct impact on the unemployment rate in this economy. As regards the long-run positive and negative shocks of this innovation, the decrease in process innovation stated a positive and significant impact on the unemployment rate whereas a positive and insignificant relationship existed between increase in process innovation and unemployment rate in the economy. The evidence presented in this study verified the findings of Pantea et al. (2017) observing, that the employment rate impact of process innovation using firm-level EUROSTAT data recorded a statistically insignificant labor-saving effect across countries and sectors.

The finding reveals the negative and significant relationship between increase in product innovation and unemployment rate whereas positive and significant nexus were detected between decrease in product innovation and unemployment in Nigeria indicating that positive and negative shocks of product innovation exhibited opposite relationship with unemployment. It suggests that the growth of demand attributed to product innovation, is a strong contributing force towards ensuring employment creation. Our finding agreed with Bogliacino et al. (2012) that employment growth is positively associated with firm expenditure in research and development biased towards product innovation.

Other results suggest causality relationship between income inequality and unemployment rate including inflation rate and unemployment rate both in the short-run and long-run. The estimated coefficient of inflation rate bore positive sign indicating a positive relationship with unemployment rate. The result failed to confirm the theory of Philip curve that there exists an inverse correlation between the two variables. It implies that persistent instability in inflation rate triggered a continuous rise in the unemployment rate in Nigeria. In addition, income inequality was observed to have dampened the growth of unemployment. It is in support of the argument that the capital intensive technological innovation via globalization exposure promotes income inequality as labour input is replaced with more productive input (job destruction), as the return of the capital owner improves at the expense of return of labour resulting an unfair distribution of compensation among production inputs (income inequality). Our findings verified that technological innovation biased towards product innovation (research and development) played a crucial role in the mitigation or de-escalation of unemployment rate, provided that, the authority can initiate effective policies to enhance quality of research and development. The effective measures towards improvement of research and development can stimulate a positive impact on globalization including technological 
innovation biased process innovation. These in turn minimize the heightening rate of unemployment in the economy and thereby promote economic growth.

\section{Concluding Remarks}

This paper investigates the impact of globalization and technological innovation on unemployment in Nigeria using quarterly time series data for the sample periods from 2000Q1 to 2018Q4 by means of the non-linear ARDL approach including Granger causality technique and variance decomposition approach which could detect dynamic interaction between globalization and technological innovation including inflation rate and income inequality as control variables. The finding suggests that our model allowed us to adopt non-linear autoregressive lags (NARDL) model to confirm the existence of a short-run and long-run asymmetric relationship between globalization (trade globalization and financial globalization), technological innovation (process innovation and product innovation) and unemployment rate which proved to be true in Nigeria. The Granger causality technique reveals a bidirectional causal relationship between main variables of interest except trade openness implying that inter-dependence and inter-connectivity of a long-term relationship existed between candidate variables of study.

However, globalization (trade globalization and financial globalization) and technological innovation biased process innovation are among parameters that contribute to the heightened magnitude of unemployment in Nigeria except technological innovation biased product innovation based on our findings. Although, Qadri et al. (2018) insisted that bad connectivity and mismanagement between globalization and technological innovation allowed social inequalities and consequently unemployment tends to emerge. The policy implication is that there is a need for the authority to initiate socially suitable and economic schemes and strategies by ensuring effective and efficient connectivity between globalization and technology via integrating science, technology, research and development including innovations. To achieve these, an enabling environment must be established that supports and promotes sound and credible government institutions and education, comprising technical education and IT skills. Lastly, designing adequate mechanisms that must ensure optimum utilization of the limited resources and avoid their embezzlement by corrupt authority officials.

\section{References}

Adamu, P., Kaliappan, S. R, Banib, Y., \& Norb, M. M. (2017). Impact of Globalization on Unemployment in SubSaharan African (SSA) Countries. Global Conference on Business and Economics Research (GCBER), Universiti Putra Malaysia, Malaysia.

Andrews, D., Chiara, C., \& Peter, N. Gal. (2016). The Best versus the Rest. OECD Productivity Working Papers, 5. https://doi.org/ 10.1787/63629cc9-en.

Anyanwu, J. C. (2014). Does Intra-African Trade Reduce Youth Unemployment in Africa? African Development Review, 26(2), 286-309. https://doi.org/10.1111/1467-8268.12082

Aremo, A. G., \& Adele, A. M. (2010). Empirical Analysis of the Impact of Globalization on Labor Force Utilization: Evidence from Nigeria. African Economic and Business Review, 8(1).

Autor, D., David, D., Katz, L., Patterson, C., \& John Van Reenen, J. V. (2017). Concentrating on the Fall of the Labor Share. W23108. Cambridge, MA: National Bureau of Economic Research. Retrieved from http://www.nber.org/papers/w23108.pdf

Awad, A., \& Youssof, I. (2016). The Impact of Economic Globalization on Unemployment: The Malaysian Experience. The Journal of International Trade and Economic Development, 25(7), 938-958.

Balcerzak, A. P., \& Zurek, M. (2011). Foreign Direct Investment and Unemployment: VAR Analysis for Poland in The Years 1995-2009. European Research Studies, 14(1), 3-14.

Bhattacharya, A., Bürkner, H., \& Bijapurkar, A. (2016). What You Need to Know about Globalisation's Radical New Phase. Retrieved from Boston Consulting Group Website www.bcgperspectives.com.content/articles/globalisation-growth-what-needknow-globalisation-radical-newphase

Bogliacino, F., Piva, M., \& Vivarelli, M. (2012). R\&D and Employment: An Application of The LSDVC Estimator Using European Microdata. Economic Letters, 116(1), 56-59.

Chella, N., \& Phiri, A. (2017). Long Run Co-Integration between Foreign Direct Investments, Domestic Investment and Unemployment in South Africa. Munich Personal Repec Archive Paper Number 82371. retrieved from https://mpra.ub.uni-muenchen.de/82371

Dachs, B., Hud, M., Koehler, C., \& Peters, B. (2017). Employment Effects of Innovations over The Business Cycle: 
Firm-Level Evidence from European Countries. SPRU Working Paper Series. SPRU-University of Sussex, Brighton.

Daly, V., Ullah, F., Rauf, A., \& Khan, G. Y. (2017). Globalization and Unemployment in Pakistan. 1-16.

Dritsakis, N., \& Stamatiou, P. (2014). Exports, Foreign Direct Investment and Economic Growth for Five European Countries: Granger Causality Tests in Panel Data. Applied Economics Quarterly, 60(4), 253-272.

Elejalde, R., Giuliodori, D., \& Stucchi, R. (2015). Employment and Innovation: Firm-Level Evidence from Argentina. Emerging Markets Finance and Trade, 51(1), 27-47.

Evangelista, R., \& Savona, M. (2010). The Impact of Innovation On Employment In Services: Evidence from Italy. International Review of Applied Economics, 16(3), 309- 318.

Felbermayr, G., Julien, P., \& Schmerer, H. (2011). Trade and Unemployment: What Do The Data Say? European Economic Review, 55, 741-758. http://doi:10.1016/j.euroecorev.2011.02.003.

Feldmann, H. (2013). Technological Unemployment in Industrial Countries. Journal of Evolutionary Economics, 1099-1126.

Fukao, K., Keuchi, K., Kim, Y. G., \& Kwon, H. U. (2017). Innovation and Employment Growth in Japan: Analysis Based on Microdata from The Basic Survey Of Japanese Business Structure and Activities. Japanese Economic Review, 68(2), 200-216.

Görg, H., \& Görlich, D. (2012). Trade and Labour Market Outcomes in Germany, In Lippoldt, D. (Ed), Policy Priorities for International Trade and Jobs, OECD. E-Publication. Retrieved from www.Oecd.Org/Trade/Icite

Harrison, R., Jaumandreu, J., Jacques, M., \& Peters, B. (2014). Does Innovation Stimulate Employment? A FirmLevel Analysis Using Comparable Micro-Data from Four European Countries. International Journal of Industrial Organization, 35, 29- 43.

Helpman, E., \& Itskhoki, O. (2010). Labor Market Rigidities, Trade and Unemployment. Review of Economic Studies, 77, 1100-1137. https://doi.org/10.1111/j.1467- 937x.2010.00600

Irpan, H. M., Saad, R. M., Nor, A. H. S. M., Noor, A. H. M., \& Ibrahim, N. (2016). Impact of Foreign Direct Investment on the Unemployment Rate in Malaysia. Journal of Physics: Conference Series.

Janiak, A. (2013). Does Trade Liberalization Lead to Job Loss? Theory and Some Evidence. Retrieved 22 May, from http://www.riksbank.se/upload/dokument_riksbank/kat_foa/janiak.pdf

Johnny, N., Timipere, E. T, Krokeme, O., \& Markjackson, D. (2018). Impact of Foreign Direct Investment on Unemployment Rate in Nigeria (1980-2015). International Journal of Academic Research in Business and Social Science.

Kilic, C. (2015). Effects if Globalization on Economic Growth: Panel Data Analysis For Developing Countries. Economic Insight- Trend and Challenges, IV, 1-11.

Kim, J. (2011). The Effects of Trade on Unemployment: Evidence from 20 OECD Countries. Stockholm: Department of Economics, Stockholm University.

Krugman, P. (2012). Capital-Biased Technological Progress: An Example (Wonkish). [Blog] New York Times Blog. Retrieved Aug. 23, 2017 from Https://Krugman.Blogs.Nytimes.Com/2012/12/26/CapitalBiasedtechnological- Progress-An-Example-Wonkish

Lachenmaier, S., \& Rottmann, H. (2011). Effects of Innovation on Employment: A Dynamic Panel Analysis. Int. J. Ind. Organ., 29, 210-220.

Lipsey, R. E., Sjöholm, F., \& Sun, J. (2010). Foreign Ownership and Employment Growth in Indonesian Manufacturing, NBER Working Paper, No. 15936.

Matthew, A. O., \& Ogunlusi, T. (2017). Foreign Direct Investment and Employment Generation in Nigeria. Proceedings of ADVED 2017-3rd International Conference on Advances in Education and Social Sciences 9-11 October, Istanbul, Turkey, 1078-1088.

Matuzeviciute, K., Butkus. M., \& Karaliute, A. (2017). Do Technological Innovations Affect Unemployment? Some Empirical Evidence from European Countries Economies. MDPI.

Meidani, N. A., \& Zabihi, M. (2012). The Dynamic Effect of Globalization in Unemployment Rate in Iran: A CoIntegration Analysis. International Business Research.

Nwaka, I. D., Uma, K. E., \& Tuna, G. (2015). Trade Openness and Unemployment: Empirical Evidence for Nigeria. 
The Economic and Labour Relations Review, 26(1), 117- 136.

Okumu, I. M., Baale, E., \& Guloba, M. M. (2019). Innovation and Employment Growth: Evidence From Manufacturing Firms in Africa. Journal of Innovation and Entrepreneurship.

Onanuga, A. T., \& Onanuga, O. T. (2018). Government Policy, Foreign Direct Investment And Unemployment in Emerging Economiesacta, Universitatis Danubius. Economica, 14(2).

Orji, A., Nwosu, E. O., Onyinye, I., \& Mba, P. N. (2016). ICT Usage and Unemployment Rate Nexus in Nigeria: An Empirical Analysis. Journal of Internet Banking and Commerce. Retrieved from http://www.icommercecentral.com

Pantea, S., Sabadash, A., \& Biagi, F. (2017). Are ICT Displacing Workers In The Short Run? Evidence from Seven European Countries. Inf. Econ. Policy, 39, 36-44.

Pesaran, M. H., \& Shin, Y. (1999). An Autoregressive Distributed Lag Modeling Approach to Cointegration Analysis. In Econometrics and Economic Theory in the 20th Century: The Ragnar Frisch centennial symposium, Edited by S. Strom. Cambridge: Cambridge University Press.

Pesaran, M. H., Shin, Y., \& Smith, R. J. (2001) Bounds Testing Approaches to the Analysis of Level Relationships. Journal of Applied Econometrics, 16, 289-326.

Piva, M., \& Vivarelli, M (2017). Technological Change and Employment: Were Ricardo and Marx Right? IZA Institute, Labor Economics Discussion Paper Series No. 10471.

Qadri, B., \& Bhat, M. (2018). Interface between Globalization and Technology. Asian Journal of Managerial Science, 7(3), 1-6. retrieved from www.trp.org.in

Raifu, I. A. (2017). On the Determinants of Unemployment in Nigeria: What are the Roles of Irade Openness and Current Account Balance? Review of Innovation and Competitiveness: Journal of Economic and Social Research, 3(4), 5-30.

Raji, R. O. (2019). Issues of Unemployment in Nigeria; Effect of Real Exchange Rate and Inflation Interaction, Quarterly Journal of Econometrics Research, 5(1), 17-28.

Sepehrdoust, H., \& Khodaee, H. (2013). The Impact of Information and Communication Technology on Employment of Selected OIC Countries. African Journal of Business Management, 7, 4149-4154.

Shaar, S. M., Hussain, E. N., \& Halim, S. M. (2012). Impact of Foreign Direct Investment on Unemployment Rate and Economic Growth in Malaysia. Journal of Applied Science Research, 8(9), 4900-4906.

Shin, Y., Yu, Greenwood, B., \& Nimmo, M. (2011). Modeling Asymmetric Cointegration and Dynamic Multiplier in a Nonlinear ARDL Framework, Mimeo.

Stewart, I., Debapratim, D. \& Alex, C. (2015). Technology and People: The Great Job- Creatingmachine. Retrieved from https://www2.deloitte.com/uk/en/pages/finance/articles/technology-and-people.html

Strata, V. A., Davidescu, A. A., \& Paul, A. M. (2014). FDI and The Unemployment - A Causality Analysis for The Latest EU Members. 2nd Global Conference on Business, Economics, Management and Tourism, 30-31 October, Prague, Czech Republic. Retrieved from www.sciencedirect.com

Vashisht, P. (2017). Destruction or Polarization: Estimating the Impact of Technology on Jobs in Indian Manufacturing. Indian Council for Research on International Economic Relations Working Paper No.334. Zdravkovic, A., Dukic, M. and Bradic-Martinovic, A. (2017). Impact of FDI on Unemployment in Transition Countries: Panel Co-Integration Approach. Industrija, 45(1), 161-174.

Zeb, N., \& Qiang, F. (2014). Foreign Direct Investment and Unemployment Reduction in Pakistan. International Journal of Economics and Research, 5(02), 10-17.

\section{Copyrights}

Copyright for this article is retained by the author(s), with first publication rights granted to the journal.

This is an open-access article distributed under the terms and conditions of the Creative Commons Attribution license (http://creativecommons.org/licenses/by/4.0/). 